\title{
Discovering ecosemiotics
}

\author{
Winfried Nöth, Kalevi Kull
}

Ecosemiotics (or ecological semiotics) is the study of sign processes in the interaction of humans with their natural environment. This semiotic field at the crossroads of nature and culture is closely related to its neighbouring fields of biosemiotics and semiotics of culture, but semiosis in the relation between humans and nature is also of concern to aesthetics, the visual arts, literature, hermeneutics, and theology. Aspects related to ecosemiotics have also been studied in human ecology, cultural geography, ecopsychology, and ecolinguistics.

There are two different conceptions of the ecological aspects of semiotics: (1) Ecological refers to all environmental information except for the one communicated by humans or in the case of other organisms by conspecifics. In this sense, there is ecological semiosis in all organisms, and ecosemiotics comprises a large part of biosemiotics.

(2) In a narrower sense ecological refers to the environment of humans only. Accordingly, human environmental problems, when treated semiotically, belong to the field of ecosemiotics. In this sense, ecosemiotics is a part of anthroposemiotics, and more strictly, of the semiotics of culture. Four major models of the relationship between humans and their environment can be discerned in the history of culture: the pansemiotic, the magical, the mythological, and the one of the natural sciences (see also Nöth 1998; 2000: 251252).

Due to these two different meanings of 'ecological', there have been different definitions of 'ecosemiotics'. For instance, Tembrock (1997) follows the first, whereas Kull (1998) follows the second definition.

First outlines of ecosemiotics and semiotic ecology can be found in the special issue of Zeitschrift für Semiotik 18(1) entitled 'Natur, Umwelt, Zeichen' (1996) or in the papers by Nöth and Kull in Sign Systems Studies 26

\footnotetext{
Authors' addresses: W. Nöth - Anglistik/Romanistik, University of Kassel, Georg-Forster-Str. 3, D-34109 Kassel, Germany; e-mail: noeth@uni-kassel.de; K. Kull - Department of Semiotics, University of Tartu, Tiigi St. 78, 50410 Tartu, Estonia; e-mail: kalevi@zbi.ee.
} 
(1998). Other special issues of journals dedicated to the topic are American Journal of Semiotics 11(1/2), entitled 'Refiguring Debris' (1994), Zeitschrift für Semiotik 19(1/2), entitled 'Zur kultursemiotischen Funktion von Gärten und Parks' (1997), and Sign Systems Studies 28 (2000), with two articles on the topic. As a university course, ecosemiotics has been included into the curriculum of Tartu University (since 1998) and of the Estonian Agricultural University (since 1999). As an applied field, ecosemiotics may have a growing importance for landscape planning and for environmental studies in general (see, e.g., Böhme 1997, Cantrill and Oravec 1996, Larsen and Grgas 1994, Posner 1990, Schempp et al. 1997, Simmons 1993, Wrede and Adams 1994).

A workshop on Ecosemiotics: Studies in Environmental Semiosis has been held in the framework of the Nordic-Baltic Summer Institute for Semiotic and Structural Studies at Imatra, Finland, on June 16-17, 2000. Considering the potential importance of this new field of semiotics and its potential for bridging the cultural and scientific aspects of ecology, it seems worthwhile to point out few details of this event as one of the first meetings in the field.

The contributions to the workshop were subdivided in three parts:

\section{Theoretical Foundations:}

Winfried Nöth (Germany) - Introduction to ecosemiotics: studies in environmental semiosis;

Kalevi Kull (Estonia) - Inter-species relations in change: an ecosemiotic analysis;

Søren Brier (Denmark) - Cybersemiotics, biosemiotics and ecosemiotics;

Solomon Marcus (Romania) - The semiotics of ecology in a mathematical perspective;

Andreas Weber (Germany) - Turning the inside out: natural forms as expression of intentionality.

\section{Cultural Ecosemiotics:}

Osmo Kuusi (Finland) - Ecosemiotics of materials;

Christina Ljungberg (Switzerland) - (Mis)reading the signs: problems of interaction in contemporary Canadian fiction;

Hannele Kerosuo (Finland) - Border zones as places of change;

Peter Schulz (Switzerland) - Subjectivity in an semiotic perspective;

Alexander E. Sedov (Russia) - New Russian myths concerning genetic research in the mass-media and in the common mind;

Dario Martinelli (Italy) - To beast or not to beast? That is the question;

Tuomo Jämsä (Finland) - Ecology of the human nature.

\section{Verbal and Nonverbal Ecosemiotics:}

Zdzisław Wąsik and Elżbieta Wasik (Poland) - On the ecological properties of languages: searching for a descriptive model in the domain of external linguistics (on the basis of Aroumunian and Frisian); 
Isabelle Guaïtella (France) — Rôle du geste et de la voix pour l'expression des attitudes dans l'interaction;

Serge Santi (France) - Fondations sensori-motrices des relations voix/gestes dans la communication;

Albert Di Cristo (France) - Une grammaire écologique comme cadre interprétatif de la prosodie de la parole;

Riste Keskpaik (Estonia) - Semiotics of garbage in Estonian press;

Magnus S. Magnusson (Iceland) - Genes and the music of human interactions.

The abstracts of the papers were published as a booklet (Abstracts - NordicBaltic Summer Institute for Semiotic and Structural Studies. Imatra, 2000) for the participants. The session included a general discussion about the relationships between ecosemiotics, biosemiotics, and semiotics of culture. Despite some overlap between these fields, there remains much to be explored.

An important challenge for ecosemiotics will be a systematic analysis of models of semiotic relationships between humans and their environment, both in historical and in contemporary cultures (cf. Böhme 1996, Bouissac 1989, Hornborg 1996, Krampen 1989, Nöth 1998, Oelschlaeger 1991, Rapp 1981, Warnke 1998). This work has only begun.

\section{References}

Böhme, Gernot 1997. Aesthetic knowledge of nature. Issues in Contemporary Culture and Aesthetics 5: 37-45.

Böhme, Hartmut 1996. Über vormoderne Naturkonzepte. Zeitschrift für Semiotik 18(1): 19-22.

Bouissac, Paul 1989. What is human? Ecological semiotics and the new animism. Semiotica 77: 497-516.

Cantrill, James G. and Oravec, Christine L. (eds.) 1996. The Symbolic Earth: Discourse and our Creation of the Environment. Lexington: The University Press of Kentucky.

Hornborg, Alf 1996. Ecology as semiotics: Outlines of a contextualist paradigm for human ecology. In: Descola, Philippe and Pálsson, Gisli (eds.), Nature and Society: Anthropological Perspectives. London: Routledge, 45-62.

Krampen, Martin 1989. An ecological approach to semiotics. In: Koch, Walter A. (ed.), Evolution of Culture. Bochum: Universitätsverlag Dr. Norbert Brockmeyer, 117-133.

Kull, Kalevi 1998. Semiotic ecology: Different natures in the semiosphere. Sign Systems Studies 26: 344-371.

Larsen, Svend Erik and Grgas, Stipe (eds.) 1994. The Construction of Nature: A Discursive Strategy in Modern European Thought. Odense: Odense University Press.

Nöth, Winfried 1998. Ecosemiotics. Sign Systems Studies 26: 332-343.

- 2000. Handbuch der Semiotik. Stuttgart: J. B. Metzler. 
Oelschlaeger, Max 1991. The Idea of Wilderness: From Prehistory to the Age of Ecology. New Haven: Yale University Press.

Posner, Roland (ed.) 1990. Warnungen an die ferne Zukunft: Atommüll als Kommunikationsproblem. München: Raben.

Rapp, F. (ed.) 1981. Naturverständnis und Naturbeherrschung. München: Fink.

Schempp, Dieter; Frantz, Jürgen; Krampen, Martin and Weißinger, Sabine (eds.) 1997. Mensch, Raum und Pflanze. Braunschweig: Thalacker Verlag.

Simmons, I. G. 1993. Interpreting Nature: Cultural Constructions of the Environment. London: Routledge.

Tembrock, Günter 1997. Ökosemiose. In: Posner, Roland; Robering, Klaus and Sebeok, Thomas A. (eds.), Semiotik: Ein Handbuch zu den zeichentheoretischen Grundlagen von Natur und Kultur, vol. 1. Berlin: de Gruyter, 571591.

Warnke, Camilla 1998. Schellings Idee und Theorie des Organismus und der Paradigmawechsel der Biologie um die Wende zum 19. Jahrhundert. Jahrbuch für Geschichte und Theorie der Biologie 5: 187-234

Wrede, Stuart and Adams, William Howard (eds.) 1994. Denatured Visions: Landscape and Culture in the Twentieth Century. New York: The Museum of Modern Art. 